\title{
Consistent increase in Indian monsoon rainfall and its variability across CMIP-5 models
}

\author{
A. Menon ${ }^{1,2}$, A. Levermann ${ }^{1,2}$, J. Schewe ${ }^{1}$, J. Lehmann ${ }^{1,2}$, and K. Frieler ${ }^{1}$ \\ ${ }^{1}$ Potsdam Institute for Climate Impact Research, 14473 Potsdam, Germany \\ ${ }^{2}$ Institute of Physics, University of Potsdam, 14476 Potsdam, Germany \\ Correspondence to: A. Menon (menon@pik-potsdam.de)
}

Received: 3 December 2012 - Published in Earth Syst. Dynam. Discuss.: 7 January 2013

Revised: 27 May 2013 - Accepted: 24 July 2013 - Published: 28 August 2013

\begin{abstract}
The possibility of an impact of global warming on the Indian monsoon is of critical importance for the large population of this region. Future projections within the Coupled Model Intercomparison Project Phase 3 (CMIP-3) showed a wide range of trends with varying magnitude and sign across models. Here the Indian summer monsoon rainfall is evaluated in 20 CMIP-5 models for the period 1850 to 2100. In the new generation of climate models, a consistent increase in seasonal mean rainfall during the summer monsoon periods arises. All models simulate stronger seasonal mean rainfall in the future compared to the historic period under the strongest warming scenario RCP-8.5. Increase in seasonal mean rainfall is the largest for the RCP-8.5 scenario compared to other RCPs. Most of the models show a northward shift in monsoon circulation by the end of the 21st century compared to the historic period under the RCP-8.5 scenario. The interannual variability of the Indian monsoon rainfall also shows a consistent positive trend under unabated global warming. Since both the long-term increase in monsoon rainfall as well as the increase in interannual variability in the future is robust across a wide range of models, some confidence can be attributed to these projected trends.
\end{abstract}

\section{Introduction}

Indian summer monsoon rainfall affects the lives of the large population of India by determining its water availability as well as food security (Parthasarathy et al., 1988; Auffhammer et al., 2006). About $80 \%$ of the annual precipitation over India occurs during the monsoon months from June to
September (Kripalani et al., 2003; Turner and Annamalai, 2012), and the released latent heat plays an important role in the atmospheric circulations as well as the radiative heat budget of the region (Webster, 1972). Even after achieving growth in service and industrial sectors, agriculture plays a vital role in the economy of the country as it is the predominant occupation in the rural regions of India. Extreme rainfall events and crop failure have adverse effects on the millions of inhabitants as well as the national economy. Hence it is of critical importance to understand how the monsoon will change under future warming, in order to take sufficient adaptation measures.

Changes in the Indian monsoon under global warming are still a matter of intense scientific debate (e.g., Sabade et al., 2011; Turner and Annamalai, 2012). An analysis of observational data for the past $130 \mathrm{yr}$ shows no clear evidence of the effect of global warming on Indian monsoon rainfall strength and its interannual variability (Mooley and Parthasarathy, 1984; Kripalani et al., 2003; Guhathakurta and Rajeevan, 2008). While no clear trend can be found for monsoon rainfall averaged over India as a whole (Mooley and Parthasarathy, 1984; Guhathakurta and Rajeevan, 2008), observations show significant trends in rainfall over several smaller regions of the country (Jagannathan and Parthasarathy, 1973; Kumar et al., 1992; Guhathakurta and Rajeevan, 2008). Some subdivisions of India show a positive trend in monsoon rainfall, while some show a significant negative trend, whereas there are some small regions that do not show any significant trends (Kumar et al., 1992; Guhathakurta and Rajeevan, 2008). Observations based on a $1^{\circ} \times 1^{\circ}$ gridded daily dataset suggest that 
monsoon rainfall in a homogeneous region over central India shows no significant long-term trend during the past few decades (Goswami et al., 2006). Even though the frequency and magnitude of extreme events show a rising trend over central India (Rajeevan et al., 2006; Goswami et al., 2006), a significant trend is absent in seasonal mean rainfall. This is attributed to a decrease in the frequency of moderate events (Goswami et al., 2006). A study by Fu et al. (1999) shows an increase in the Indian monsoon rainfall in relation to an abrupt warming around the year 1920 .

By contrast several ice core records and speleothem records show a decreasing trend in the Indian summer monsoon (ISM) rainfall in the last century. ISM rainfall intensity measured from the Dasuopu ice core shows a decreasing trend during the past century (Thompson et al., 2000; Duan et al., 2004). ISM intensity from speleothem record over southern Arabia also shows a decreasing trend over the past century, which is attributed to the increase in sea surface temperature over the Indian Ocean (Burns et al., 2002). The ISM intensity reconstructed from a tree ring record over Tibetan Plateau also shows a decreasing trend from 1860 to present (Xu et al., 2012).

Models have their own limitations in capturing the regional rainfall accurately (Turner and Annamalai, 2012). While some model studies find very little impact on the all India monsoon rainfall in transient and time-slice climate change experiments (Mahfouf et al., 1994; Lal et al., 1994; Timbal et al., 1995; Lal et al., 1995), some others suggest an increase in the mean Indian monsoon precipitation as well as the interannual variability under enhanced warming (Meehl and Washington, 1993; Kitoh et al., 1997; Hu et al., 2000; Lal et al., 2001; Cubasch et al., 2001; May, 2002; Fan et al., 2012). A study (Ashfaq et al., 2009) based on a high-resolution nested model suggests a suppression in the Indian monsoon rainfall in the future, which is attributed to a weakening of the monsoon circulation and a suppression of the intraseasonal modes. CMIP-5 models consistently project a significant increase in Indian summer monsoon rainfall sub-seasonal variability under unmitigated climate change (Menon et al., 2013). The Hamburg COSMOS model shows a complex behavior with changing skewness of the rainfall distribution and an associated increase in monsoon failure events (Schewe and Levermann, 2012). A subset of the IPCC AR4 models suggest an increase in the strength of the monsoon precipitation (Kripalani et al., 2007), whereas the monsoon circulation is projected to weaken (Tanaka et al., 2005; Ueda et al., 2006), while earlier studies using slab ocean models suggest a strengthening of monsoon precipitation as well as the circulation (Zhao and Kellogg, 1988). The projected precipitation from few CMIP-3 models, which are considered more realistic, shows a range of trends including negative trends in monsoon rainfall by 2100 (Turner and Annamalai, 2012) under the SRES A1B scenario. Cherchi et al. (2011) analyze global monsoons based on a fully coupled atmosphere-ocean general circulation model and suggest that the Indian summer monsoon intensifies in the future, mainly in response to the increased moisture content under various $\mathrm{CO}_{2}$ forcings. Studies based on CMIP-5 models under RCP-4.5 scenario project an increase in global mean precipitation of around $3.2 \% \mathrm{~K}^{-1}$ (Hsu et al., 2013) and a larger increase in annual mean precipitation over the entire Asian monsoon region with less uncertainty as compared to CMIP-3 models (Lee and Wang, 2012). Compared to CMIP3 models, CMIP-5 models have higher horizontal and vertical resolution in the atmosphere and ocean, and they have a more detailed representation of aerosols. Some of the CMIP5 models have a more complete representation of the carbon cycle compared to CMIP-3 models. Sperber et al. (2012) suggest that, because of the higher spatial resolution, CMIP5 models have a better representation of rainfall compared to CMIP-3 models, especially in the vicinity of steep topography (like Western Ghats). CMIP-5 models outperform CMIP-3 models in simulating the monsoon annual cycle, the onset of monsoon as well as the time of the monsoon peak. The spatial extent of monsoon in CMIP-5 multi-model mean (MMM) is more realistic than in the CMIP-3 MMM. The magnitude of intra-seasonal variance is also more realistic in CMIP-5 MMM compared to CMIP-3 MMM. Both CMIP5 and CMIP-3 MMM capture low-level monsoon circulation quite well with pattern correlations of 0.98 and 0.97 respectively, compared to ERA40 observational dataset. Even though the time-mean rainfall error has a consistent pattern between CMIP-5 and CMIP-3 MMM, the amplitude of error is less for CMIP-5 MMM compared to CMIP-3 MMM (Sperber et al., 2012).

Aerosols play an important role in shaping monsoons over South Asia. IPCC Fourth Assessment Report (Meehl et al., 2007) examined the role of scattering aerosols like sulfate aerosols in monsoons. The presence of sulfate aerosols over South Asia masks the effect of increased temperature gradient by greenhouse gases by reflecting the solar radiation and thereby reducing the land warming and hence the thermal contrast. Recent studies consider the effect of black carbon aerosols on South Asian monsoons (Ramanathan et al., 2005; Meehl et al., 2008) and suggest that a "business as usual" black carbon scenario can result in about $25 \%$ decrease in mean monsoon rainfall by the mid-21st century. Some of the models also show a projected increase in the rainfall interannual variability. However, the seasonal projection of interannual variability of South Asian monsoon rainfall is a major challenge (Sperber and Palmer, 1996; Goswami, 1998). Multi-decadal fluctuations are also present in the Indian summer monsoon rainfall and are forced mainly by the tropical sea surface temperatures, and partly by extra-tropical oscillations like Atlantic multidecadal oscillation (Kucharski et al., 2009). Indian monsoon rainfall shows considerable decrease from late 1950 s to 1990 s. Kucharski et al. (2009) use CMIP-3 models to show that the increase in greenhouse gases (GHGs) in the 20th century has not contributed significantly to the observed Indian summer monsoon decadal variability. 


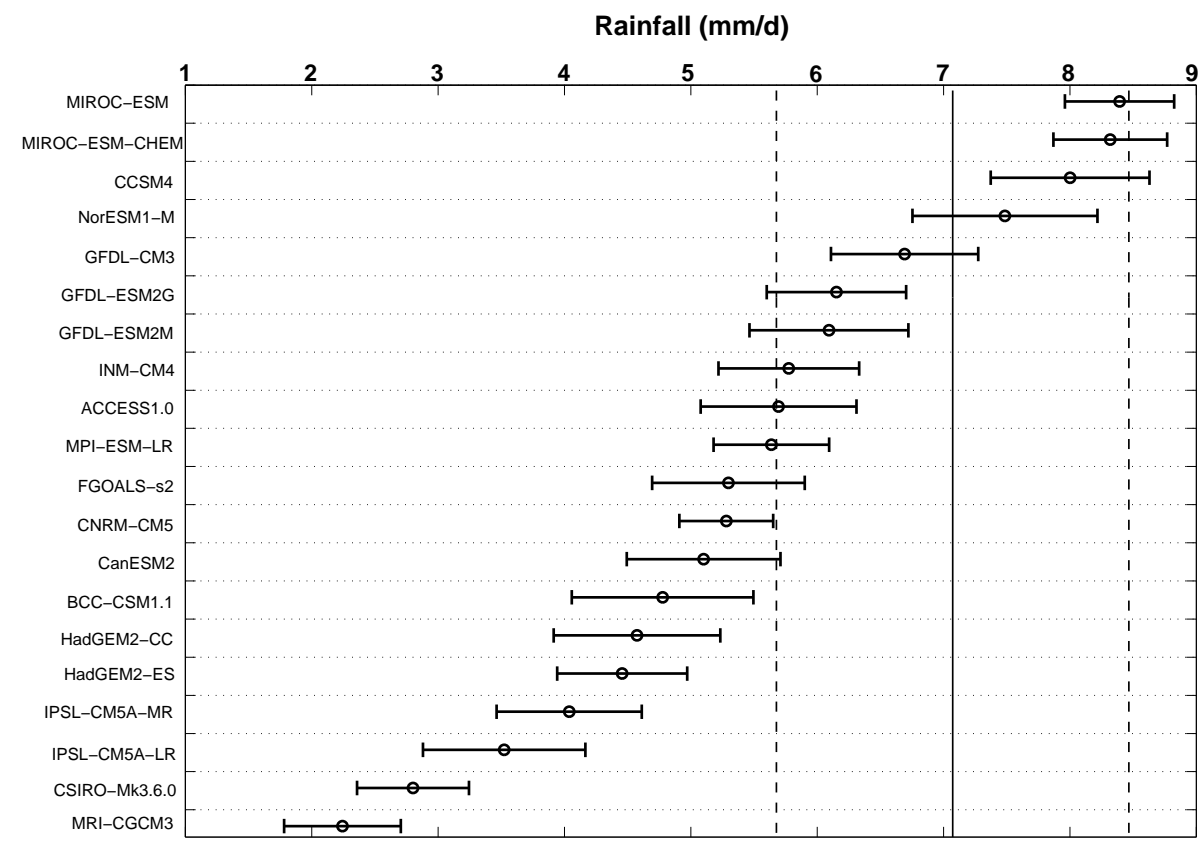

Fig. 1. JJAS mean rainfall over all India region from different models for the historic period. The black vertical line shows the all India mean monsoon rainfall from observations for the period 1871-2004, and the dashed lines show mean plus/minus twice the standard deviation of all India mean rain. Circles with error bars represent mean and mean plus/minus one standard deviation for the 20 comprehensive models from 1871 to 2004 .

In order to capture the full range of possible future scenarios, including mitigation strategies, the Representative Concentration Pathways (RCPs) have been developed as a basis for the IPCC fifth assessment report. There are four RCPs categorized according to their approximate radiative forcing in the year 2100. We use data from RCP model simulations in order to study the projected changes in the mean and variability of ISM rainfall in the future. In this study, we examine the mid-19th century to the end of the 21 st century variability of ISM rainfall simulated by 20 of the models that participated in the CMIP-5. Section 2.1 shows a brief model evaluation of the Indian summer monsoon mean rainfall. Section 2.2 gives the trend in all India mean monsoon rainfall and Sect. 2.3 its interannual variability in the RCP-based simulations. Section 2.4 deals with the changes in monsoon circulation in the future. The results are discussed in Sect. 3.

\section{Results}

\subsection{Model evaluation}

In this study, we use simulated rainfall obtained from 20 of the models that participated in the CMIP-5. Models are chosen according to the availability of the data: only those models are analyzed for which data for historic period (18502005), RCP-8.5 and at least one more scenario were available at the time of the study. The model information is summarized in Table 1. The range in global mean temperature as constrained by past climate observations allows for a wide range of responses within an RCP (Schewe et al., 2011). Historical simulations are based on solar and volcanic forcing, land use, observed concentrations of greenhouse gases, and reconstructed aerosol emissions. Future projections are based on the four Representative Concentration Pathways (RCPs) (Moss et al., 2010). RCP-8.5 is the pathway for which radiative forcing reaches $8.5 \mathrm{~W} \mathrm{~m}^{-2}$ by 2100 . Similarly RCP4.5 and RCP-6.0 represent the pathways for which radiative forcing reaches 4.5 and $6 \mathrm{~W} \mathrm{~m}^{-2}$ in 2100 . RCP-2.6 peaks in radiative forcing at $3 \mathrm{~W} \mathrm{~m}^{-2}$ before 2100 and declines afterwards reaching $2.6 \mathrm{~W} \mathrm{~m}^{-2}$ in 2100 . India as a whole (allIndia) is selected for the study, and data are masked over all-India region. Mean rainfall is obtained by averaging the June-September (JJAS) rainfall over the all-India land region and denoted as all-India summer monsoon rainfall (AISMR). The all-India rainfall dataset from Parthasarathy et al. (1994) is used to compare the seasonal mean rainfall from models during historical periods with observations. The observational data cover a period from 1871 to 2004 .

In order to identify models with a potentially realistic representation of the monsoon rainfall, we compare their long-term seasonal mean with the observed precipitation (Parthasarathy et al., 1994) for the period 1871 to 2004 (Fig. 1). The climatological mean rainfall from observations is $7.1 \mathrm{~mm} \mathrm{day}^{-1}$, with a standard deviation of $0.7 \mathrm{~mm} \mathrm{day}^{-1}$. About half of the models capture seasonal mean rainfall within twice the standard deviation (vertical dashed lines in 
Table 1. Details of the data availability for the 20 comprehensive models used in the study. Only those models are selected for which data for historic period, RCP-8.5 and at least one more scenario are available at the time of the study.

\begin{tabular}{|c|c|c|c|c|c|}
\hline Modeling Center (Group) & Model & $\mathrm{RCP}-8.5$ & RCP-6.0 & $\mathrm{RCP}-4.5$ & RCP-2.6 \\
\hline $\begin{array}{l}\text { Commonwealth Scientific and } \\
\text { Industrial Research } \\
\text { Organization (CSIRO) and } \\
\text { Bureau of Meteorology } \\
\text { (BOM), Australia }\end{array}$ & ACCESS 1.0 & $\mathrm{Y}$ & $\mathrm{N}$ & $\mathrm{Y}$ & $\mathrm{N}$ \\
\hline $\begin{array}{l}\text { Beijing Climate Center, China } \\
\text { Meteorological Administration }\end{array}$ & BCC-CSM1.1 & Y & Y & Y & Y \\
\hline $\begin{array}{l}\text { Canadian Centre for Climate } \\
\text { Modelling and Analysis }\end{array}$ & CanESM2 & $\mathrm{Y}$ & $\mathrm{N}$ & $\mathrm{Y}$ & $\mathrm{Y}$ \\
\hline $\begin{array}{l}\text { National Center for } \\
\text { Atmospheric Research }\end{array}$ & CCSM4 & $\mathrm{Y}$ & $\mathrm{Y}$ & $\mathrm{Y}$ & $\mathrm{Y}$ \\
\hline $\begin{array}{l}\text { Centre National de Recherches } \\
\text { Météorologiques/Centre Européen } \\
\text { de Recherche et Formation } \\
\text { Avancées en Calcul Scientifique }\end{array}$ & CNRM-CM5 & $\mathrm{Y}$ & $\mathrm{N}$ & $\mathrm{Y}$ & $\mathrm{Y}$ \\
\hline $\begin{array}{l}\text { Commonwealth Scientific and } \\
\text { Industrial Research Organization } \\
\text { in collaboration with Queensland } \\
\text { Climate Change Centre of Excellence }\end{array}$ & CSIRO-Mk3.6.0 & $\mathrm{Y}$ & $\mathrm{Y}$ & $\mathrm{Y}$ & $\mathrm{Y}$ \\
\hline $\begin{array}{l}\text { LASG, Institute of Atmospheric } \\
\text { Physics, Chinese Academy of } \\
\text { Sciences }\end{array}$ & FGOALS-s2 & $\mathrm{Y}$ & $\mathrm{Y}$ & Y & Y \\
\hline \multirow{3}{*}{$\begin{array}{l}\text { NOAA Geophysical Fluid } \\
\text { Dynamics Laboratory }\end{array}$} & GFDL-CM3 & Y & Y & $\mathrm{N}$ & Y \\
\hline & GFDL-ESM2G & $\mathrm{Y}$ & Y & $\mathrm{Y}$ & $\mathrm{Y}$ \\
\hline & GFDL-ESM2M & $\mathrm{Y}$ & $\mathrm{Y}$ & $\mathrm{Y}$ & $\mathrm{Y}$ \\
\hline Met Office Hadley Centre & $\begin{array}{l}\text { HadGEM2-CC } \\
\text { HadGEM2-ES }\end{array}$ & $\begin{array}{l}\mathrm{Y} \\
\mathrm{Y}\end{array}$ & $\begin{array}{l}\mathrm{N} \\
\mathrm{Y}\end{array}$ & $\begin{array}{l}\mathrm{Y} \\
\mathrm{Y}\end{array}$ & $\begin{array}{l}\mathrm{N} \\
\mathrm{Y}\end{array}$ \\
\hline $\begin{array}{l}\text { Institute for Numerical } \\
\text { Mathematics }\end{array}$ & INM-CM4 & $\mathrm{Y}$ & $\mathrm{N}$ & $\mathrm{Y}$ & $\mathrm{N}$ \\
\hline Institut Pierre-Simon Laplace & $\begin{array}{l}\text { IPSL-CM5A-LR } \\
\text { IPSL-CM5A-MR }\end{array}$ & $\begin{array}{l}\mathrm{Y} \\
\mathrm{Y}\end{array}$ & $\begin{array}{l}\mathrm{Y} \\
\mathrm{N}\end{array}$ & $\begin{array}{l}\mathrm{Y} \\
\mathrm{Y}\end{array}$ & $\begin{array}{l}\mathrm{Y} \\
\mathrm{Y}\end{array}$ \\
\hline \multirow[t]{2}{*}{$\begin{array}{l}\text { Japan Agency for Marine-Earth } \\
\text { Atmosphere and Ocean Research } \\
\text { Science and Technology, } \\
\text { Institute (The University of } \\
\text { Tokyo), and National Institute } \\
\text { for Environmental Studies }\end{array}$} & MIROC-ESM & $\mathrm{Y}$ & $\mathrm{Y}$ & $\mathrm{Y}$ & $\mathrm{Y}$ \\
\hline & MIROC-ESM-CHEM & $\mathrm{Y}$ & $\mathrm{Y}$ & Y & Y \\
\hline $\begin{array}{l}\text { Max Planck Institute for } \\
\text { Meteorology }\end{array}$ & MPI-ESM-LR & Y & $\mathrm{N}$ & Y & Y \\
\hline $\begin{array}{l}\text { Meteorological Research } \\
\text { Institute }\end{array}$ & MRI-CGCM3 & $\mathrm{Y}$ & $\mathrm{Y}$ & $\mathrm{Y}$ & $\mathrm{Y}$ \\
\hline Norwegian Climate Centre & NorESM1-M & Y & Y & Y & Y \\
\hline
\end{tabular}


Fig. 1) of the observed mean for the period 1871 to 2004. Models like MIROC-ESM and MIROC-ESM-CHEM show a slight overestimation of seasonal mean rainfall, while models like CSIRO-Mk3 and MRI-CGCM3 show an underestimation. The error bars in Fig. 1 represent long-term standard deviations for each of the models under consideration, and the values vary from 0.4 to 0.7 for various models. NorESM1$\mathrm{M}$ and GFDL-CM3 capture the mean rainfall closest to the observed mean. The spatial pattern of JJAS rainfall climatology over India (Fig. 2), from the India Meteorological Department observational dataset (Rajeevan et al., 2006), shows that the mean precipitation is highest over the south-west coast, central India and the north-east India. The spatial patterns of rainfall during the monsoon season as simulated by all models are shown in Fig. 3. The models that underestimate the climatological rainfall do not capture the spatial pattern of monsoon well. CSIRO-Mk3.6.0 and MRI-CGCM3 model more rainfall over the east coast of Bay of Bengal and the tropical Indian Ocean. They show very low rainfall over the all-India region. Similarly, the Hadley Centre models (HadGEM2-CC and HadGEM2-ES) and the Institute Pierre Simon Laplace models (IPSL-CM5A-LR and IPSLCM5A-MR) capture very little rainfall over the all-India region with comparatively higher rainfall over the Himalayan mountains and the Bay of Bengal.

As discussed by Levermann et al. (2009), the monsoon region can enter a climatic regime in which latent heat transport towards land is insufficient to sustain a monsoon circulation, which may lead to abrupt monsoon transition (Zickfeld et al., 2005) as observed in the past (Schewe et al., 2012; Cook et al., 2010; Sinha et al., 2011). While observations clearly show that the ISM is currently within the active monsoon regime, it is possible that the CMIP-5 models that exhibit a very weak ISM are outside this regime. In this study, we decide to interpret the results of the future monsoon evolution from models with historical mean precipitation below the observed mean minus twice its standard deviation $\left(5.7 \mathrm{~mm} \mathrm{day}^{-1}\right)$ as well as the ones with an unrealistic spatial pattern, with care as they are less likely to provide a good approximation of the real evolution. Full information is, however, provided for all models.

\subsection{Long-term trend in Indian monsoon rainfall under various RCP warming scenarios}

AISMR is analyzed for the four RCPs (Figs. 4 and 5). AISMR shows a clear positive long-term trend in all models under the RCP- 8.5 scenario, whereas the long-term trend is small under RCP-2.6 scenario (Fig. 4). And even for the lowest concentration scenario RCP-2.6, only 3 out of 20 models show a small decreasing trend in rainfall. Under RCP-8.5 scenario, the majority of the models simulate rainfall response outside the envelope of the baseline variability (black horizontal lines) towards the end of the 21st century. FGOALS-s2 shows a rainfall response beyond the baseline

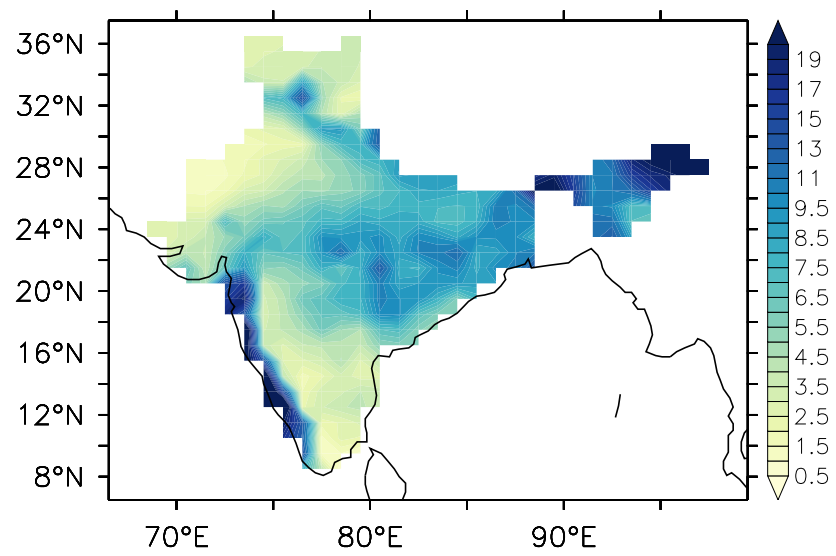

Fig. 2. June-September (JJAS) rainfall climatology (mm/day) during the period 1970-2000 from the India Meteorological Department (IMD) daily gridded observational dataset. Mean precipitation is highest over south-west peninsular India, north-east India and central India.

variability from the beginning of the 21st century onwards under all RCP scenarios. The percentage changes in the AISMR ( $\delta$ mean) by the end of the 21 st century (2070-2100) with respect to the pre-industrial period (1870-1900) under all RCPs are summarized in Fig. 6. Models listed in the upper panel of Fig. 6 are those that capture the AISMR well with mean rainfall for the historic period (1871-2004) falling within twice the standard deviation $\left(0.7 \mathrm{~mm} \mathrm{day}^{-1}\right)$ of the observed mean $\left(7.1 \mathrm{~mm} \mathrm{day}^{-1}\right)$. The relative increase in mean monsoon rainfall is less (up to $<15 \%$ ) for these models compared to the ones with a much lower historic mean. The significance of $\delta$ mean values are obtained from a Student's $t$ test, and it shows that 19 out of the 20 models show a significant increase in $\delta$ mean under the RCP-8.5 scenario at a $95 \%$ confidence level. MPI-ESM-LR shows a slight increase in the AISMR during the end of the 21 st century compared to the pre-industrial period under RCP- 8.5 scenario, which is not significant at a $95 \%$ confidence level. MRICGCM3 shows the maximum increase in AISMR of about $60 \%$ by the end of the 21 st century compared to the end of the 19th century for RCP-8.5 and RCP-6.0 scenarios. But as shown in Fig. 3, MRI-CGCM3 does not capture the spatial pattern of AISMR realistically. All models show a consistent increase in $\delta$ mean at $95 \%$ confidence level under all scenarios. None of the negative values of $\delta$ mean are significant at a $95 \%$ confidence level. In summary, a consistent picture of an increasing seasonal mean rainfall under global warming arises from the CMIP-5 intercomparison.

Due to the relatively fast adjustment time of the atmosphere, most models show little path dependence of the ISM change, in the sense that changes are very similar for the same increase in global mean temperature compared to preindustrial period independent of which scenario was followed. Therefore, it is possible to provide the percentage 

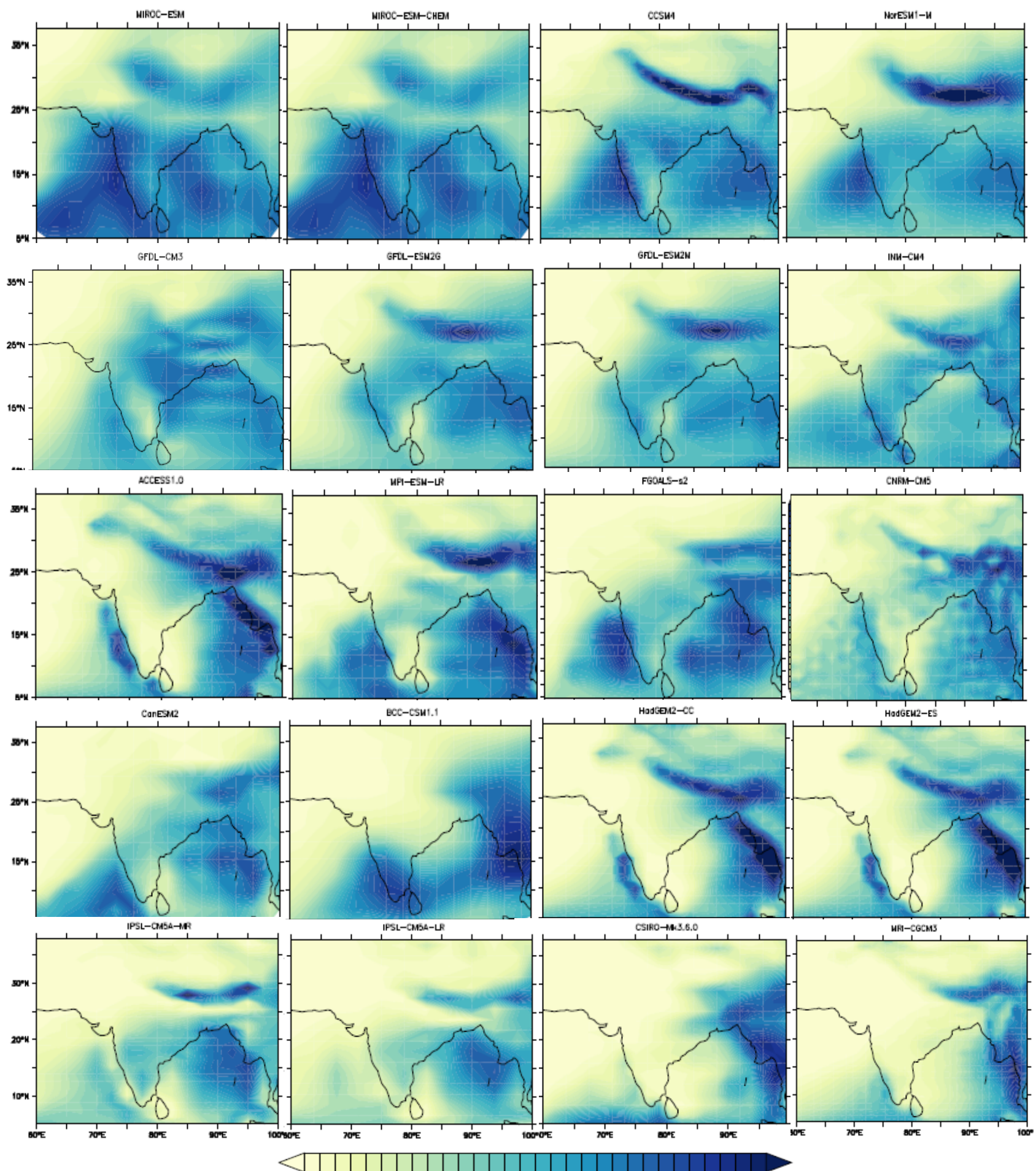

$\begin{array}{lllllllllllllll}0.5 & 1.5 & 2.5 & 3.5 & 4.5 & 5.5 & 6.5 & 7.5 & 8.5 & 9.5 & 11 & 13 & 15 & 17 & 19\end{array}$

Fig. 3. June-September (JJAS) rainfall climatology $\left(\mathrm{mm} \mathrm{day}^{-1}\right)$ during the period 1871-2004 for all 20 models. Models with lowest seasonal mean rainfall do not capture the spatial pattern realistically. The models are shown in the same order as in Fig. 1. 

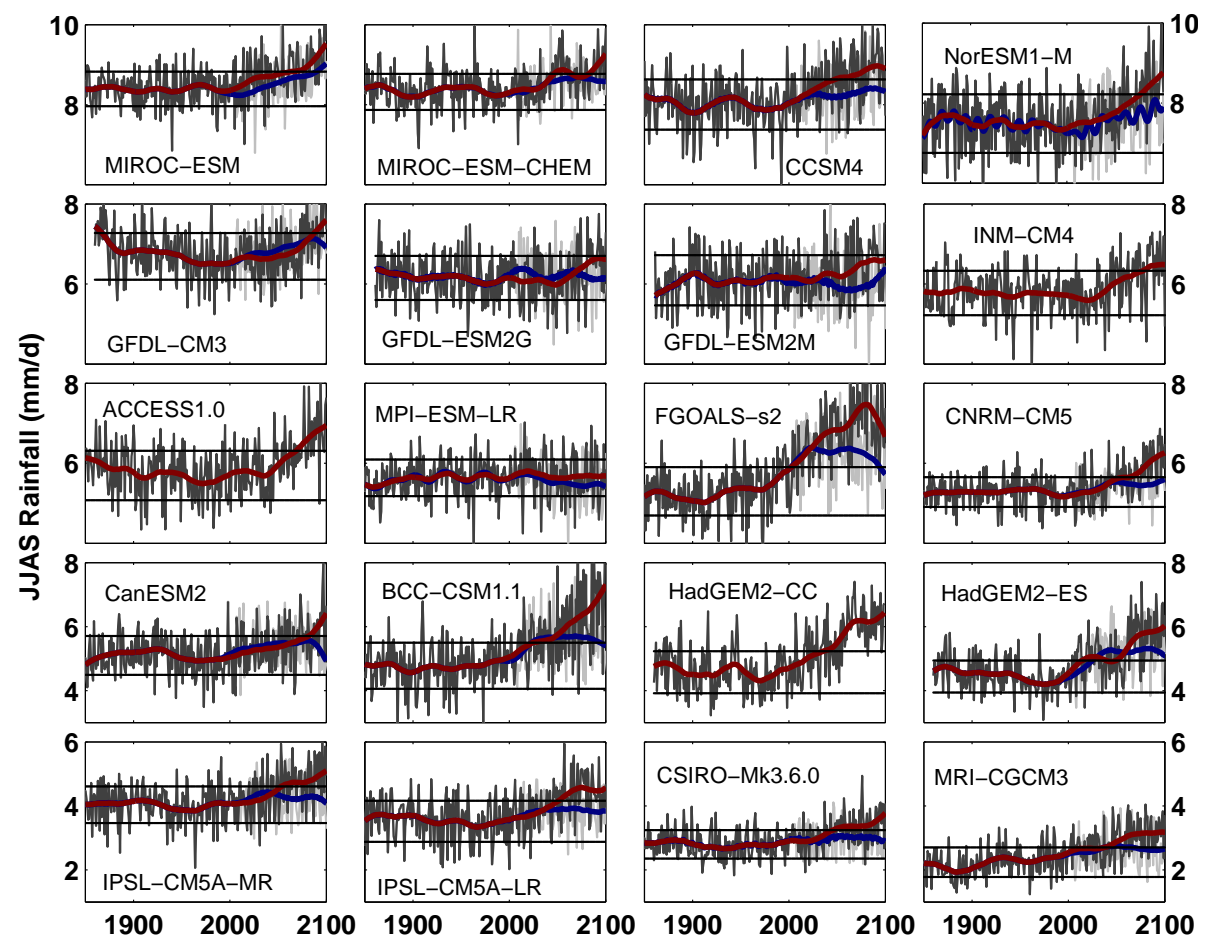

Fig. 4. Indian summer monsoon seasonal (June-September) mean rainfall for the period 1850-2100 from the 20 comprehensive climate models. Gray shadings represent the yearly values, and red and blue lines represent the nonlinear trend in seasonal mean rain obtained from a singular spectrum analysis with a window width of $21 \mathrm{yr}$ for RCP-8.5 and RCP-2.6 respectively. The non-linear trends are calculated using a routine from Aslak Grinsted, and the method is discussed in Moore et al. (2005). The horizontal black lines represent mean \pm standard deviation for each model for the period 1871-2004, which shows the range of baseline variability.
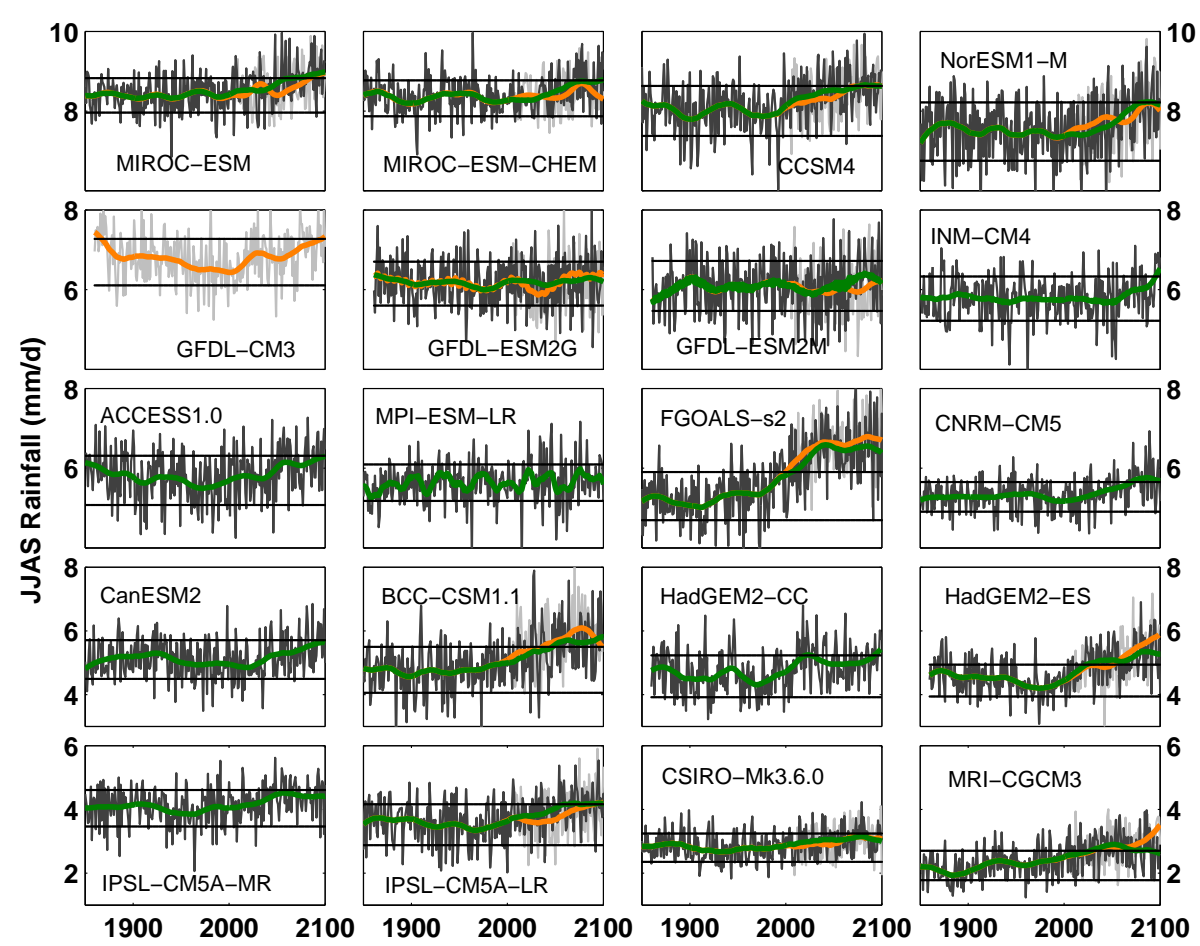

Fig. 5. Long-term trend in seasonal mean rainfall, same as in Fig. 4, but for RCP-4.5 (green) and RCP-6.0 (orange) scenarios. Horizontal black lines represent the range of baseline variability as in Fig. 4. Please refer Table 1 for the data availability for Figs. 4 and 5. 


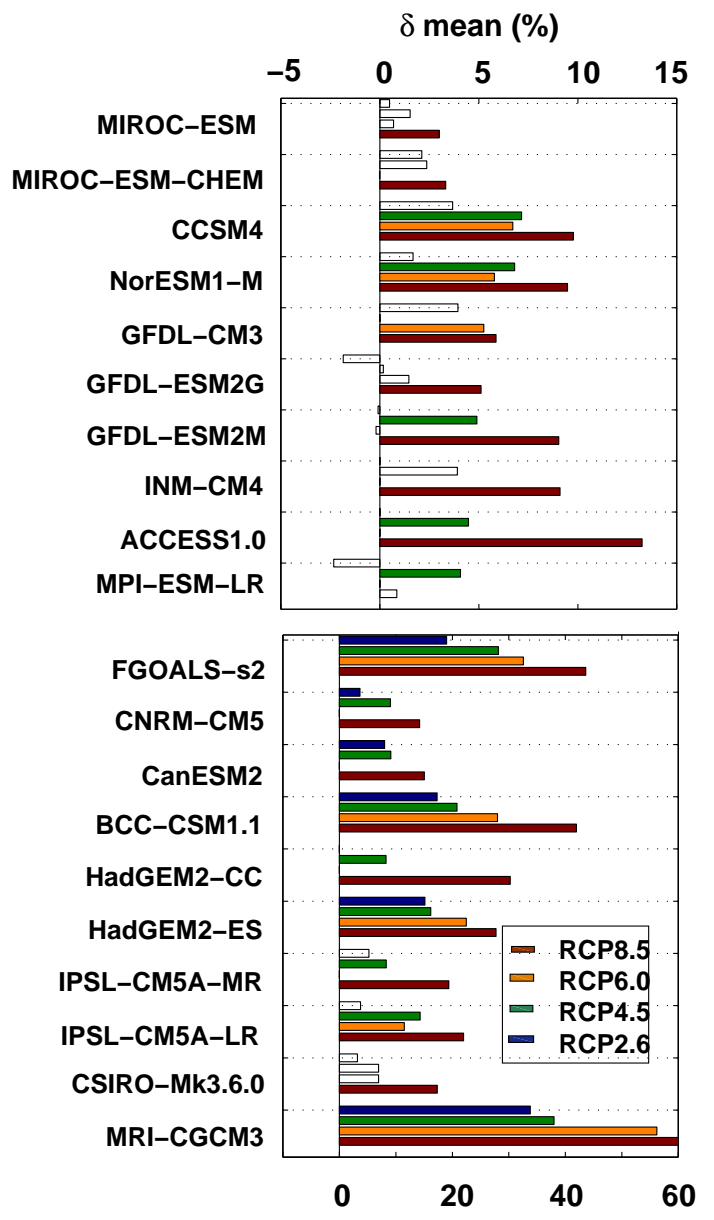

Fig. 6. Percentage change in mean rainfall for RCP-8.5 (red), RCP6.0 (orange), RCP-4.5 (green) and RCP-2.6 (blue) for all models under consideration. Relative change is calculated as the change in seasonal (JJAS) mean rainfall for the period 2070-2100 with respect to the period 1870-1900, i.e., $\left({\overline{\overline{\text { JJASrain }}_{2070-2100}}}_{1870-1900} \cdot 100\right)-100$. The gap separates models with rainfall values for 1871-2004 lying within and outside twice the standard deviation of the observed mean as per Fig. 1. Bars on the panels are transparent if the $\delta$ mean values are not significant at $95 \%$ confidence level.

change in AISMR as a function of global mean temperature change or AISMR change per degree of warming. It is given in Fig. 7. RCP-2.6 scenario is not considered here as the temperature changes are very low under this scenario. Considering only trends that are significant at a $95 \%$ confidence level, all models project an increase in the AISMR with an increase in temperature. The trends are comparatively smaller for the more realistic models. Figure 8 shows the histogram of the trends per degree kelvin. The relative changes in AISMR per degree of warming range from 1 to $19 \% \mathrm{~K}^{-1} ; 66.5 \%$ of the trends for an ensemble of all models lie in the range of 1$9 \% \mathrm{~K}^{-1}$ with a median increase of $3.2 \% \mathrm{~K}^{-1}$. While considering only the more realistic models in the upper panel of Fig. 7, $66.5 \%$ of the relative changes in AISMR per degree of

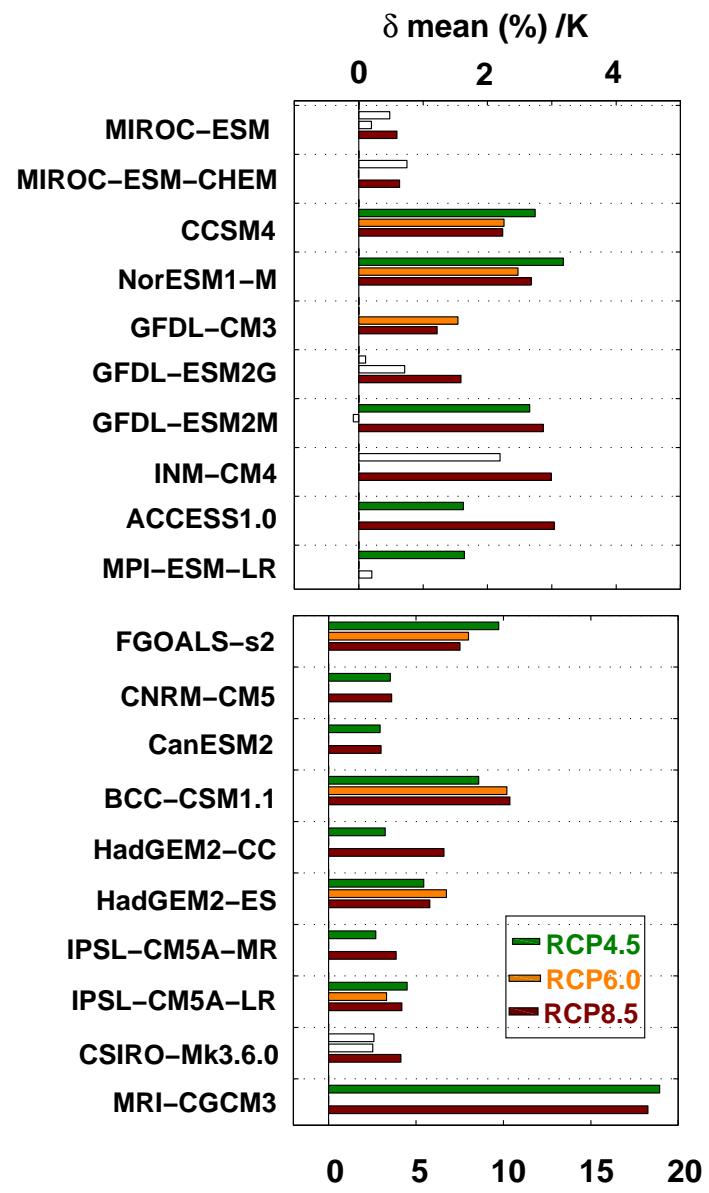

Fig. 7. Percentage change in mean rainfall per degree change in temperature for RCP-8.5 (red), RCP-6.0 (orange) and RCP-4.5 (green) for all models. As the temperature change in RCP-2.6 is very small, it is not taken into consideration. Transparent bars are the values that are not significant at $95 \%$ confidence level.

warming are in the range $1.3-3 \% \mathrm{~K}^{-1}$. These models show a median increase of $2.3 \% \mathrm{~K}^{-1}$. This value is closer to the projected increase in global mean precipitation per degree of warming $\left(2.2 \pm 0.52 \% \mathrm{~K}^{-1}\right)$ given by Frieler et al. (2011) for CMIP-3.

Figure 9 represents the changes in the spatial pattern of rainfall under the RCP-8.5 scenario compared to the historic period. The majority of the models show an increase in rainfall over almost all parts of India by the end of the 21st century compared to the end of the 20th century. GFDL-ESM2M, GFDL-ESM-2G, MPI-ESM-LR and CanESM2 show a reduction in rainfall over central India in the future but capture an increase in rainfall over other parts of India.

\subsection{Future evolution of interannual variability}

The percentage changes in long-term standard deviation for the period 2050-2100 with respect to 1900-1950 are used to analyze how the interannual variability evolves under global 


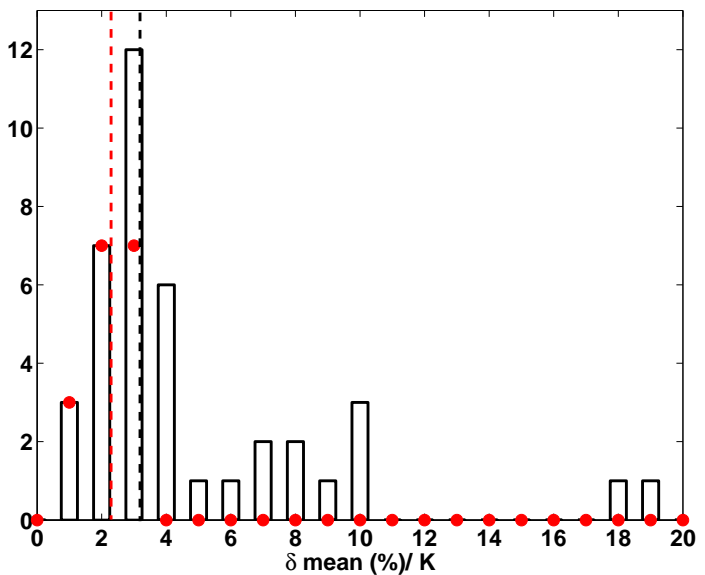

Fig. 8. Histogram of the percentage changes in mean rainfall per degree change in temperature for all significant scenarios of all models as in Fig. 7. Red dots represent the values for the models in the upper panel of Fig. 7. Black dashed line shows the median value for the ensemble of all models, and red dashed line shows the median value for the most realistic models (i.e., the ones in the upper panel of Fig. 7).

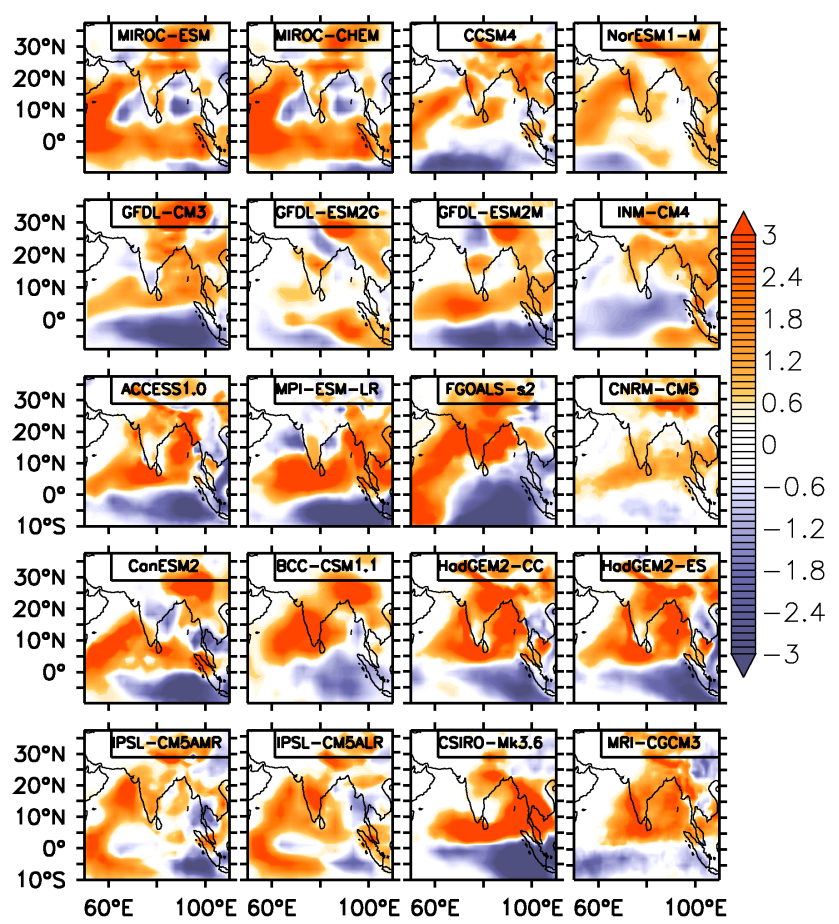

Fig. 9. JJAS rainfall composite difference $\left(\mathrm{mm} \mathrm{day}^{-1}\right)$ for the period 2070-2100 under RCP-8.5 scenario and for the period 19702000. The majority of the models capture an increase in summer monsoon mean rainfall by about $0-3 \mathrm{~mm} \mathrm{day}^{-1}$ in most parts of India.

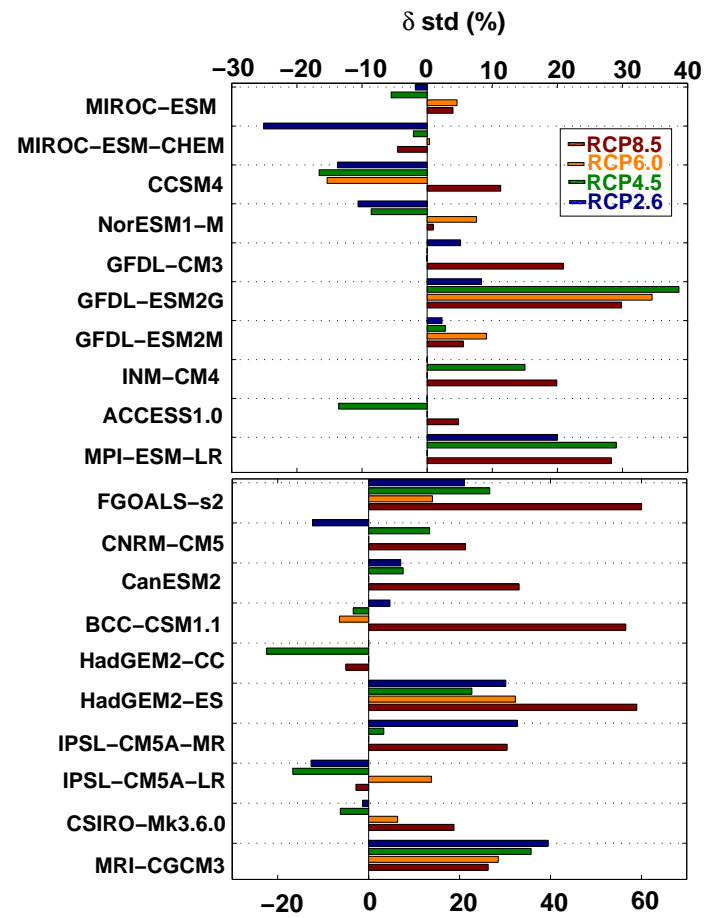

Fig. 10. The percentage change of standard deviation (STD) during the second half of 21 st century to the standard deviation during the first half of the 20th century under RCP-8.5 (red), RCP-6.0 (orange), RCP-4.5 (green)and RCP-2.6 (blue) for all models under consideration. All values greater than 0 show an increase in variability. The percentage change is given as $\left(\frac{\mathrm{STD}_{2050-2100}}{\mathrm{STD}_{1900-1950}} \cdot 100\right)-100$. The upper and lower panels are separated as in Figs. 6 and 7.

warming. The standard deviation of seasonal mean rainfall shows a positive trend in most of the models under the RCP8.5 scenario (Fig. 10) indicating an increase in interannual variability in the future. Out of the 20 models under consideration, 17 models show an increase in interannual variability under this scenario. MIROC-ESM-CHEM, HadGEM2CC and IPSL-CM5A-LR show a slight decrease $(<10 \%)$ in standard deviation by the second half of the 21 st century compared to the first half of the 20th century. It has to be noted that most models show an increase in interannual variability in the future under various concentration pathways. The largest increase is simulated by FGOALSs2, BCC-CSM1.1 and HadGEM2-ES under the RCP-8.5 scenario. CCSM4 shows a decrease in variability under all scenarios except RCP-8.5. GFDL-ESM2G, GFDL-ESM2M, FGOALS-s2, HadGEM2-ES and MRI-CGCM3 show an increase in interannual variability under all four RCPs. While HadGEM2-ES captures an increase in interannual variability under all four scenarios, HadGEM2-CC captures a decrease in interannual variability in the two available scenarios at the time of the study. But as shown earlier in Fig. 3, these two models did not capture the spatial pattern of monsoon rainfall reasonably well. Out of the few negative trends 


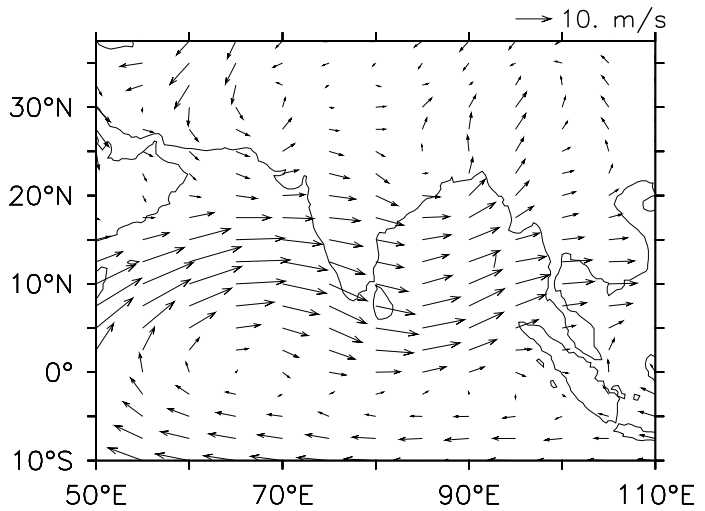

Fig. 11. June-September $850 \mathrm{hPa}$ wind $\left(\mathrm{m} \mathrm{s}^{-1}\right)$ climatology for the period 1970-2000 from NCEP/NCAR reanalysis data (Kalnay et al., 1996).

of interannual variability, most of them are under the RCP2.6 and RCP-4.5 scenarios. The interannual variability has a clear positive trend in most of the models under the higher scenarios RCP-6.0 and RCP-8.5.

\subsection{Changes in monsoon circulation in the future}

Some studies suggest a weakening of the monsoon circulation in a number of CMIP-3 models under global warming (Tanaka et al., 2005; Ueda et al., 2006). The $850 \mathrm{hPa}$ summer wind climatology from observational data shows the lowlevel monsoon circulation that carries moisture from over ocean to the Indian land region (Fig. 11). Figure 12 depicts the composite difference in the wind anomaly between the end of the 21 st century under RCP- 8.5 and the end of the 20th century from the CMIP-5 models. The majority of the models show an increase in wind speed (shaded) in the north of India and a decrease in wind speed in southern peninsular India as well as the north equatorial Indian Ocean by the end of the 21 st century. Anomalies in wind direction (vectors) are opposite to the direction of the mean wind over the southern peninsular India, and along the direction of the mean wind over central and northern India, in most of the models. This could indicate a northward shift in the monsoon circulation in the future. The ensemble mean over all 19 models under consideration also shows the same pattern (Fig. 13). This pattern resembles that of the wind anomaly from the CMIP-3 models (cf. Fig. 2a in Ueda et al., 2006). The monsoon circulation strengthens over northern India, but it weakens over the south of India. Figure 14 shows the meridional pattern of the zonal wind averaged over the longitudes $50-110^{\circ} \mathrm{E}$ for all 19 models under consideration. The majority of the models show a slight northward shift in monsoon circulation of the order of about $2^{\circ}$ by the end of the 21 st century under RCP-8.5. Kitoh et al. (1997) suggest a similar northward shift in the monsoon circulation under global warming. Such a latitudinal shift of the circulation would be important to consider when

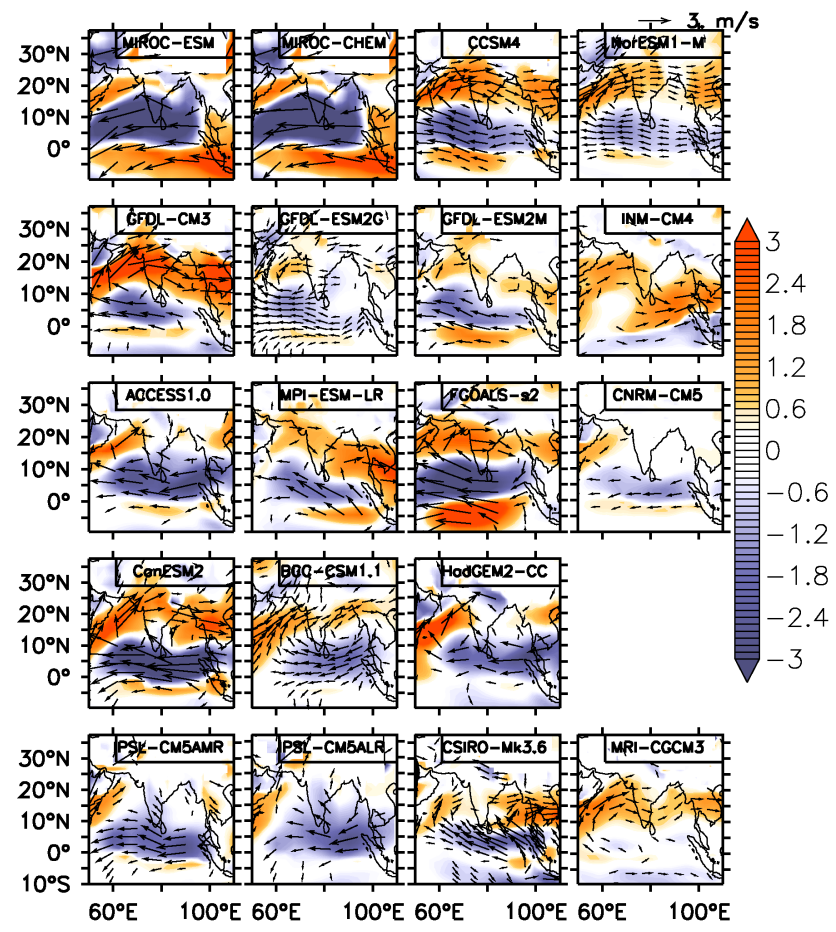

Fig. 12. Difference in wind speed (shading, in $\mathrm{ms}^{-1}$ ) and direction (vectors) during June-September for the period 2070-2100 under RCP-8.5 and 1970-2000 for 19 models under consideration. HadGEM2-ES is not shown as wind data for historic period were not available at the time of the study. Wind vector anomalies are in the direction of the mean flow over the northern parts of India and are opposite to the mean flow over the southern parts of India in most of the models.

assessing changes in the total strength of the circulation. Figure 14 shows that the overall magnitude of the zonal monsoon winds decreases in a few models (e.g., MIROC-ESM, MIROC-ESM-CHEM, IPSL-CM5A-MR, IPSL-CM5A-LR, CanESM2), but remains fairly constant in most models, or even increases in some (e.g., INM-CM4).

\section{Discussion and conclusions}

The future evolution of Indian summer monsoon rainfall and its interannual variability have been analyzed based on global coupled model simulations under the RCP scenarios. This study analyzes whether previous inconsistency between models regarding the long-term trend in the Indian summer monsoon rainfall under transient warming scenarios still exists in the CMIP-5 generation of climate models. By comparison of the models' performance with the all-India mean monsoon rainfall for the historic period from observations and examination of the spatial patterns of rainfall, we consider some models as more realistic and put more emphasis on them compared to the ones with a very weak monsoon rainfall. For these models a consistent picture arises: Indian 


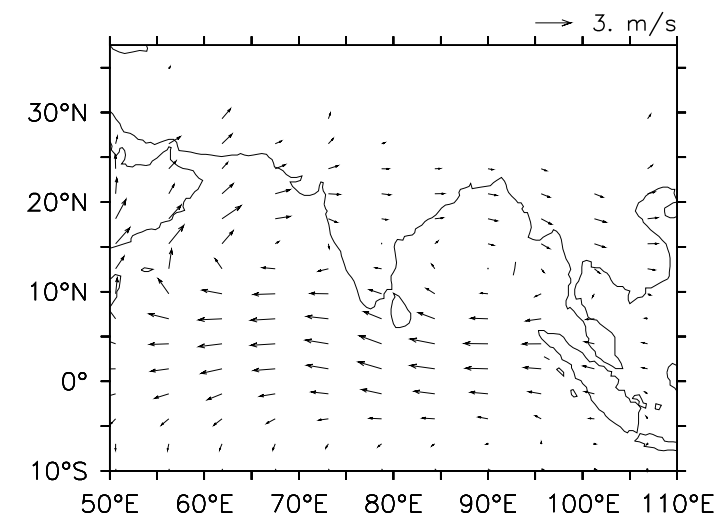

Fig. 13. Differences in June-September $850 \mathrm{hPa}$ winds $\left(\mathrm{m} \mathrm{s}^{-1}\right)$ for the period 2070-2000 (under RCP-8.5) compared to the historic period (1970-2000) for the ensemble mean of all 19 models under consideration.

summer monsoon rainfall increases under future warming. All models except MPI-ESM-LR simulate the maximum positive trend in mean monsoon rainfall under the highest concentration pathway RCP-8.5. This result agrees with $\mathrm{Fu}$ et al. (1999), who find an increase in the Indian monsoon rainfall during abrupt warming, and suggests a relationship between global temperature increase and the Indian monsoon rainfall.

An increase in seasonal mean precipitation can occur due to changes in the inter-tropical convergence zone (Hu et al., 2000). In coupled models under global warming, it has been attributed predominantly to an increase in the water-holding capacity of the atmosphere with an increase in surface temperature (Trenberth, 1998). For example, Meehl et al. (2005) suggest the increase in water vapor content associated with an increase in sea surface temperature in a warmer climate as the reason for enhanced precipitation in the tropics in some IPCC AR4 models. The atmospheric water vapor is projected to increase by $12-16 \%$ over large parts of India (Kripalani et al., 2007) at the time of $\mathrm{CO}_{2}$ doubling. This increased moisture content can lead to enhanced precipitation. In this study, we see that the increase in AISMR per degree change in temperature is about $2.3 \% \mathrm{~K}^{-1}$, which is similar to the projected increase in global mean precipitation per degree change in temperature in CMIP-3 (Frieler et al., 2011).

A second trend that emerges consistently across models in CMIP-5 is an increase in interannual variability. The monsoon variability shows a general increasing trend under various RCPs in most of the models. Rainfall variability is particularly important for societal and economic adaptation strategies, defining the required year-to-year flexibility for agricultural management, disaster preparedness, etc. Further studies are needed to understand the physical reasons behind the increase in interannual variability. One of the reasons attributed to the increase is the increase in El Niño Southern Oscillation (ENSO) variability in the future, which is transmitted to

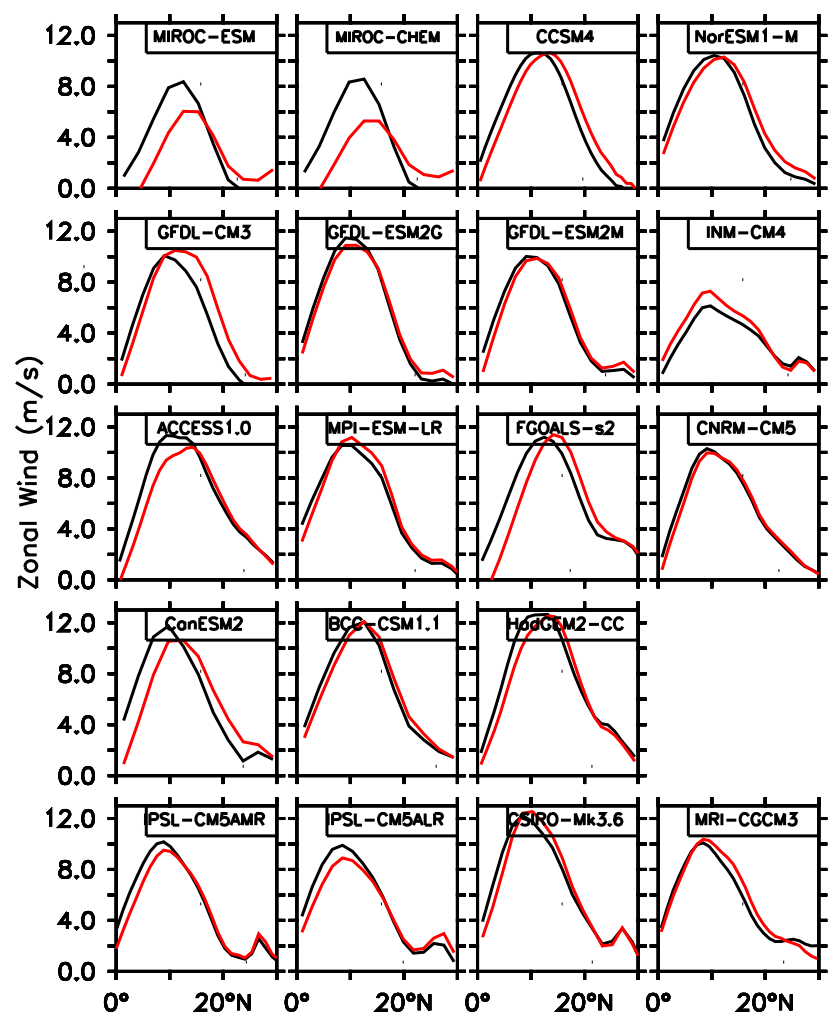

Fig. 14. Meridional pattern of zonal wind $\left(\mathrm{m} \mathrm{s}^{-1}\right)$ averaged over the region $50 \mathrm{E}-110 \mathrm{E}$ for the 19 CMIP-5 models during JuneSeptember. Black lines represent JJAS mean zonal wind for the period 1970-2000, and red lines represent JJAS mean zonal wind for the period 2070-2100.

South Asian monsoon rainfall through the Walker cell $(\mathrm{Hu}$ et al., 2000; Schewe and Levermann, 2012). Another possibility is that the enhanced variability is attributed to the increase in tropical Indian Ocean and Pacific sea surface temperatures, irrespective of the ENSO variability (Meehl and Arblaster, 2003). According to Meehl and Arblaster (2003), the Pacific Ocean SST plays a dominant role, whereas the Indian Ocean plays a secondary role in monsoon interannual variability. Also an observation-based study suggests that the increase in interannual variability of Indian summer monsoon is associated with warmer land and ocean temperatures (Meehl and Washington, 1993). CMIP-5 models show a strengthening of the monsoon circulation in the northern parts of India and a weakening of circulation in the southern parts. The majority of the models show a northward shift in the monsoon circulation under global warming. We do not aim for a consistent physical understanding across all climate models here, but concluded that most of the models that participated in the CMIP-5 show a positive trend in monsoon mean rainfall as well as its interannual variability under future warming. It can be noted that all trends in AISMR that are significant at a $95 \%$ confidence level are positive. The long-term intensification of monsoon rainfall, but even more 
so the intensification of monsoon variability, requires longterm adaptation strategies to cope with future climate change in India.

Acknowledgements. This work was funded by the BMBF PROGRESS project (support code 03IS2191B). We acknowledge the World Climate Research Programme's Working Group on Coupled Modelling, which is responsible for CMIP, and we thank the climate modeling groups (listed in Table 1) for producing and making available their model output. For CMIP, the US Department of Energy's Program for Climate Model Diagnosis and Intercomparison provided coordinating support and led development of software infrastructure in partnership with the Global Organization for Earth System Science Portals. We have used the NCEP Reanalysis Derived data provided by the NOAA/OAR/ESRL PSD, Boulder, Colorado, USA, from their website at http://www.esrl.noaa.gov/psd/.

Edited by: M. Huber

\section{References}

Ashfaq, M., Shi, Y., Tung, W., Trapp, R. J., Gao, X., Pal, J. S., and Diffenbaugh, N. S.: Suppression of south Asian summer monsoon precipitation in the 21st century, Geophys. Res. Lett., 36, L01704, doi:10.1029/2008GL036500, 2009.

Auffhammer, M., Ramanathan, V., and Vincent, J. R.: Integrated model shows that atmospheric brown clouds and greenhouse gases have reduced rice harvests in India, P. Natl. Acad. Sci., 103, 19668-19672, 2006.

Burns, S., Fleitmann, D., Mudelsee, M., Neff, U., Matter, A., and Mangini, A.: A 780-year annually resolved record of Indian Ocean monsoon precipitation from a speleothem from south Oman, J. Geophys. Res., 107, 4434, doi:10.1029/2001JD001281, 2002.

Cherchi, A., Alessandri, A., Masina, S., and Navarra, A.: Effects of increased $\mathrm{CO}_{2}$ levels on monsoons, Clim. Dynam., 37, 83-101, doi:10.1007/s00382-010-0801-7, 2011.

Cook, E. R., Anchukaitis, K. J., Buckley, B. M., Di Arrigo, R. D., Jacoby, G. C., and Wright, W. E.: Asian Monsoon Failure and Megadrought During the Last Millennium, Science, 328, 486439, 2010.

Cubasch, U., Meehl, G., Boer, G., Stouffer, R., Dix, M., Noda, A., Senior, C., Raper, S., and Yap, K.: Projections of future climate change, in: Climate Change 2001: The Scientific Basis: Contribution of Working Group I to the Third Assessment Report of the Intergovernmental Panel, edited by: Houghton, J. T., Ding, Y., Griggs, D. J., Noguer, M., Van der Linden, P. J., Dai, X., Maskell, K., and Johnson, C. A., Cambridge University Press, UK, 526-582, 2001.

Duan, K., Yao, T., and Thompson, L.: Low-frequency of southern Asian monsoon variability using a 295 -year record from the Dasuopu ice core in the central Himalayas, Geophys. Res. Lett., 31, L16209, doi:10.1029/2004GL020015, 2004.

Fan, F., Mann, M. E., Lee, S., and Evans, J. L: Future changes in the south Asian summer monsoon: An analysis of the CMIP3 multi-model projections, J. Climate, 25, 3909-3928, 2012.
Frieler, K., Meinshausen, M., von Deimling, T., Andrews, T., and Forster, P.: Changes in global-mean precipitation in response to warming, greenhouse gas forcing and black carbon, Geophys. Res. Lett., 38, L04702, doi:10.1029/2010GL045953, 2011.

Fu, C., Diaz, H., Dong, D., and Fletcher, J.: Changes in atmospheric circulation over Northern Hemisphere oceans associated with the rapid warming of the 1920s, Int. J. Climatol., 19, 581-606, 1999.

Goswami, B. N.: Interannual variations of Indian summer monsoon in a GCM: External conditions versus internal feedbacks, J. Climate, 11, 501-522, 1998.

Goswami, B. N., Venugopal, V., Sengupta, D., Madhusoodanan, M. S., and Xavier, P. K.: Increasing Trend of Extreme Rain Events Over India in a Warming Environment, Science, 314, 1442-1445, 2006

Guhathakurta, P. and Rajeevan, M.: Trends in the rainfall pattern over India, Int. J. Climatol., 28, 1453-1469, 2008.

Hsu, P.-C., Li, T., Murakami, H., and Kitoh, A.: Future change of the global monsoon revealed from 19 CMIP5 models, J. Geophys. Res.-Atmos., 118, 1-14, doi:10.1002/jgrd.50145, 2013.

Hu, Z., Latif, M., Roeckner, E., and Bengtsson, L.: Intensified Asian summer monsoon and its variability in a coupled model forced by increasing greenhouse gas concentrations, Geophys. Res. Lett., 27, 2681, doi:10.1029/2000GL011550, 2000.

Jagannathan, P. and Parthasarathy, B.: Trends and periodicities of rainfall over India, Mon. Weather Rev., 101, 371-375, 1973.

Kalnay, E., Kanamitsu, M., Kistler, R., Collins, W., Deaven, D., Gandin, L., Iredell, M., Saha, S., White, G., Woollen, J., Zhu, Y., Chelliah, M., Ebisuzaki, W., Higgins, W., Janowiak, J., Mo, K. C., Ropelewski, C., Wang, J., Leetmaa, A., Reynolds, R., Jenne, R., and Joseph, D.: The NCEP/NCAR 40-Year Reanalysis Project, B. Am. Meteorol. Soc., 77, 437-471, 1996.

Kitoh, A., Yukimoto, S., Noda, A., and Motoi, T.: Simulated changes in the Asian summer monsoon at times of increased atmospheric $\mathrm{CO}_{2}$, J. Meteorol. Soc. Jpn., 75, 1019-1031, 1997.

Kripalani, R., Kulkarni, A., Sabade, S., and Khandekar, M.: Indian monsoon variability in a global warming scenario, Nat. Hazards, 29, 189-206, 2003.

Kripalani, R. H., Oh, J. H., Kulkarni, A., Sabade, S. S., and Chaudhari, H. S.: South Asian summer monsoon precipitation variability: Coupled climate model simulations and projections under IPCC AR4, Theor. Appl. Climatol., 90, 133-159, doi:10.1007/s00704-006-0282-0, 2007.

Kucharski, F., Scaife, A. A., Yoo, J. H., Folland, C. K., Kinter, J., Knight, J., Fereday, D., Fischer, A. M., Jin, E. K., Kröger, J., Lau, N.-C., Nakaegawa, T., Nath, M. J., Pegion, P., Rozanov, E., Schubert, S., Sporyshev, P. V., Syktus, J., Voldoire, A., Yoon, J. H., Zeng, N., Zhou, T.: The CLIVAR C20C project: skill of simulating Indian monsoon rainfall on interannual to decadal timescales. Does GHG forcing play a role?, Clim. Dynam., 33, 615-627, 2009.

Kumar, K., Pant, G., Parthasarathy, B., and Sontakke, N.: Spatial and subseasonal patterns of the long-term trends of Indian summer monsoon rainfall, Int. J. Climatol., 12, 257-268, 1992.

Lal, M., Cubasch, U., and Santer, B.: Effect of global warming on Indian monsoon simulated with a coupled ocean-atmosphere general circulation model, Current Sci., 66, 430-438, 1994.

Lal, M., Cubasch, U., Voss, R., and Waszkewitz, J.: Effect of transient increase in greenhouse gases and sulphate aerosols on monsoon climate, Current Sci., 69, 752-763, 1995. 
Lal, M., Nozawa, T., Emori, S., Harasawa, H., Takahashi, K., Kimoto, M., Abe-Ouchi, A., Nakajima, T., Takemura, T., and Numaguti, A.: Future climate change: Implications for Indian summer monsoon and its variability, Current Sci., 81, 1196-1207, 2001.

Lee, J.-Y. and Wang, B.: Future change of global monsoon in the CMIP5, Clim. Dynam., 39, 1123-1135, 2012.

Levermann, A., Schewe, J., Petoukhov, V., and Held, H.: Basic mechanism for abrupt monsoon transitions, P. Natl. Acad. Sci., 106, 20572-20577, 2009.

Mahfouf, J., Cariolle, D., Royer, J., Geleyn, J., and Timbal, B.: Response of the Meteo-France climate model to changes in $\mathrm{CO}_{2}$ and sea surface temperature, Clim. Dynam., 9, 345-362, 1994.

May, W.: Simulated changes of the Indian summer monsoon under enhanced greenhouse gas conditions in a global time-slice experiment, Geophys. Res. Lett., 29, 1118, doi:10.1029/2001GL013808, 2002.

Meehl, G. A. and Arblaster, J. M.: Mechanisms for projected future changes in south Asian monsoon precipitation, Clim. Dynam., 21, 659-675, 2003.

Meehl, G. A. and Washington, W. M.: South Asian Summer Monsoon Variability in a Model with Doubled Atmospheric Carbon Dioxide Concentration, Science, 260, 1101-1104, 1993.

Meehl, G. A., Arblaster, J. M., and Tebaldi, C.: Understanding future patterns of increased precipitation intensity in climate model simulations, Geophys. Res. Lett., 32, L18719, doi:10.1029/2005GL023680, 2005.

Meehl, G. A., Stocker, T. F., Collins, W. D., Friedlingstein, P., Gaye, A. T., Gregory, J. M., Kitoh, A., Knutti, R., Murphy, J. M., Noda, A., Raper, S. C. B., Watterson, I. G., Weaver, A. J., and Zhao, Z.C.: Climate Change 2007: The Physical Science Basis, Contribution of Working Group I to the Fourth Assessment Report of the Intergovernmental Panel on Climate Change, chap. Global Climate Projections, Cambridge University Press, Cambridge, UK and New York, NY, USA, 2007.

Meehl, G. A., Arblaster, J. M., and Collins, W. D.: Effects of black carbon aerosols on the Indian monsoon, J. Climate, 21, 28692882, 2008.

Menon, A., Levermann, A., and Schewe, J.: Enhanced future variability during India's rainy season, Geophys. Res. Lett., 40, 3242-3247, doi:10.1002/grl.50583, 2013.

Mooley, D. and Parthasarathy, B.: Fluctuations in All-India summer monsoon rainfall during 1871-1978, Climatic Change, 6, 287301, 1984.

Moore, J., Grinsted, A., and Jevrejeva, S.: New tools for analyzing time series relationships and trends, EOS Trans. Am. Geophys. Union, 86, 226, 2005.

Moss, R. H., Edmonds, J. A., Hibbard, K. A., Manning, M. R., Rose, S. K., van Vuuren, D. P., Carter, T. R., Emori, S., Kainuma, M., Kram, T., Meehl, G. A., Mitchell, J. F. B., Nakicenovic, N., Riahi, K., Smith, S. J., Stouffer, R. J., Thomson, A. M., Weyant, J. P., and Wilbanks, T. J.: The next generation of scenarios for climate change research and assessment, Nature, 463, 747-756, 2010.

Parthasarathy, B., Munot, A., and Kothawale, D.: Regression model for estimation of Indian foodgrain production from summer monsoon rainfall, Agr. Forest Meteorol., 42, 167-182, doi:10.1016/0168-1923(88)90075-5, 1988.
Parthasarathy, B., Munot, A., and Kothawale, D.: All-India monthly and seasonal rainfall series: 1871-1993, Theor. Appl. Climatol., 49, 217-224, 1994.

Rajeevan, M., Bhate, J., Kale, J. A., and Lal, B.: High resolution daily gridded rainfall data for the Indian region: Analysis of break and active monsoon spells, Current Sci., 91, 296-306, 2006.

Ramanathan, V., Chung, C., Kim, D., Bettge, T., Kiehl, J. T., Washington, W. M., Fu, Q., Sikka, D. R., and Wild, M.: Atmospheric brown clouds: Impacts on South Asian climate and hydrological cycle, P. Natl. Acad. Sci., 102, 5326-5333, 2005.

Sabade, S., Kulkarni, A., and Kripalani, R.: Projected changes in South Asian summer monsoon by multi-model global warming experiments, Theor. Appl. Climatol., 103, 543-565, 2011.

Schewe, J. and Levermann, A.: A statistically predictive model for future monsoon failure in India, Environ. Res. Lett., 7, 044023, doi:10.1088/1748-9326/7/4/044023, 2012.

Schewe, J., Levermann, A., and Meinshausen, M.: Climate change under a scenario near $1.5^{\circ} \mathrm{C}$ of global warming: monsoon intensification, ocean warming and steric sea level rise, Earth Syst. Dynam., 2, 25-35, doi:10.5194/esd-2-25-2011, 2011.

Schewe, J., Levermann, A., and Cheng, H.: A critical humidity threshold for monsoon transitions, Clim. Past, 8, 535-544, doi:10.5194/cp-8-535-2012, 2012.

Sinha, A., Berkelhammer, M., Stott, L., Mudelsee, M., Cheng, H., and Biswas, J.: The leading mode of Indian Summer Monsoon precipitation variability during the last millennium, Geophys. Res. Lett., 38, L15703, doi:10.1029/2011GL047713, 2011.

Sperber, K. and Palmer, T.: Interannual tropical rainfall variability in general circulation model simulations associated with the Atmospheric Model Intercomparison Project, J. Climate, 9, 27272750, 1996.

Sperber, K. R., Annamalai, H., Kang, I.-S., Kitoh, A., Moise, A., Turner, A., Wang, B., and Zhou, T.: The Asian summer monsoon: an intercomparison of CMIP5 vs. CMIP3 simulations of the late 20th century, Clim. Dynam., doi:10.1007/s00382-012-1607-6, in press, 2012.

Tanaka, H., Ishizaki, N., and Nohara, D.: Intercomparison of the intensities and trends of Hadley, Walker and monsoon circulations in the global warming projections, SOLA, 1, 77-80, 2005.

Thompson, L., Yao, T., Mosley-Thompson, E., Davis, M., Henderson, K., and Lin, P.: A high-resolution millennial record of the South Asian monsoon from Himalayan ice cores, Science, 289, 1916-1919, 2000.

Timbal, B., Mahfouf, J., Royer, J., and Cariolle, D.: Sensitivity to prescribed changes in sea surface temperature and sea ice in doubled carbon dioxide experiments, Clim. Dynam., 12, 1-20, 1995.

Trenberth, K.: Atmospheric moisture residence times and cycling: Implications for rainfall rates and climate change, Climatic Change, 39, 667-694, 1998.

Turner, A. and Annamalai, H.: Climate change and the South Asian summer monsoon, Nat. Clim. Change, 2, 587-595, 2012.

Ueda, H., Iwai, A., Kuwako, K., and Hori, M.: Impact of anthropogenic forcing on the Asian summer monsoon as simulated by eight GCMs, Geophys. Res. Lett., 33, L06703, doi:10.1029/2005GL025336, 2006.

Webster, P.: Response of the tropical atmosphere to local, steady forcing, Mon. Weather Rev., 100, 518-541, 1972. 
Xu, H., Hong, Y., and Hong, B.: Decreasing Asian summer monsoon intensity after $1860 \mathrm{AD}$ in the global warming epoch, Clim. Dynam., 39, 2079-2088, doi:10.1007/s00382-012-1378-0, 2012.

Zhao, Z. and Kellogg, W.: Sensitivity of soil moisture to doubling of carbon dioxide in climate model experiments, Part II: The Asian monsoon region, J. Climte, 1, 367-378, doi:10.1175/15200442(1988)001<0367:SOSMTD>2.0.CO;2, 1988 .
Zickfeld, K., Knopf, B., Petoukhov, V., and Schellnhuber, H. J.: Is the Indian summer monsoon stable against global change?, Geophys. Res. Lett., 32, L15707, doi:10.1029/2005GL022771, 2005. 